\title{
Reusable tourniquets. An underestimated means for patient transfer of multi-resistant bacteria
}

\author{
T Gottlieb*, T Phan, EYL Cheong, G Sala, S Siarakas, A Pinto \\ From International Conference on Prevention \& Infection Control (ICPIC 2011) \\ Geneva, Switzerland. 29 June - 2 July 2011
}

\section{Introduction / objectives}

We sought to investigate the use of reusable tourniquets as potential sources of MRO transmission.

\section{Methods}

100 reusable tourniquets were collected over 10 weeks in a 503-bed Sydney teaching hospital. Tourniquets were incubated overnight in BHI enrichment broth and subcultured.

\section{Results}

The colonisation rate was $78 \%$ (78/100). Ten grew non multi-resistant Gram- positives - MSSA (1) and Enterococcus species (9), 17 grew commensals. Non multiresistant Gram-negatives grew in 38 specimens: Pseudomonas species (13) and 'coliforms' (26). MROs were found on $25 \%$ of tourniquets, including 3 from MRO isolation rooms. An IMP-4 positive E. cloacae and an ESBL $E$. cloacae were isolated from a single tourniquet each. MRSA was isolated from 14; vanB E. faecium was isolated from 18 and vanA E. faecalis from a single tourniquet. MRSA and VRE were isolated together from nine tourniquets, and 24 tourniquets grew either one. Van B positive E. faecium were typed using DiversiLab rep-PCR system This revealed five clusters without adominant clone. Six of 9 tourniquets from ICU grew at least one MRO. MROs were isolated throughout the 10 week period from a wide variety of locations including general wards, ICU, Burns, theatre anaesthetic bay and the blood collection unit.

\section{Conclusion}

Reusable tourniquets are frequently colonised with MROs and may be a potential source of cross-transmission. Using broth enrichment, $24 \%$ harboured either

Microbiology and Infectious Diseases, Concord Hospital, Concord, Australia
MRSA or VRE. Astourniquets are carried from ward to ward by hospital staff and used repeatedly, they may become a 'sleeper' mechanism for unrecognised hospital MRO transmission. They are also a surrogate marker for environmental colonisation and deficiencies in hospital cleaning. Continued use of reusable tourniquets may not be justified in the current hospital setting.

\section{Disclosure of interest}

None declared.

Published: 29 June 2011

doi:10.1186/1753-6561-5-S6-P38

Cite this article as: Gottlieb et al:: Reusable tourniquets. An

underestimated means for patient transfer of multi-resistant bacteria. BMC Proceedings 2011 5(Suppl 6):P38.
Submit your next manuscript to BioMed Central and take full advantage of:

- Convenient online submission

- Thorough peer review

- No space constraints or color figure charges

- Immediate publication on acceptance

- Inclusion in PubMed, CAS, Scopus and Google Scholar

- Research which is freely available for redistribution
() Bïomed Central 